\title{
Evaluation of Earthworm Species and Bedding Material Collected from Tea Plantations for Vermicomposting in Sri Lanka
}

\author{
Hitinayake H.M.G.S.B. ${ }^{1}$, Ubayapala K.G.K.C. ${ }^{1}$, Samaranayake J.K.S. ${ }^{2}$ and \\ Weerasekera W.A.T.H. ${ }^{1}$
}

\author{
${ }^{1}$ Department of Crop Science, Faculty of Agriculture, University of Peradeniya, Peradeniya, Sri Lanka. \\ ${ }^{2}$ Division of Seed Certification Service and Plant Protection Center, Department of Agriculture, Peradeniya, Sri Lanka. \\ Email: gaminisbh@gmail.com
}

\begin{abstract}
Earthworms has the ability to convert organic waste into compost and this process is known as vermicomposting. This study was conducted to evaluate the suitability of three common earthworm species and four waste material collected from tea plantations as bedding material for earthworms in producing vermicompost. Three experiments were conducted and the experimental design was a Complete Randomized Design with three replicates.

In the first experiment, four bedding materials that is leaves of Gliricidia (Gliricidia sepium) and Mana (Cymbopogon confertiflorus), tea prunings and refuse tea were composted using earthworm species Eudrilus euginea. Each waste material was mixed with cow dung and poultry manure, separately before using them as bedding material. The results showed that these material can be used for producing high quality vermicompost. In the second experiment three earthworm species Eisenia foetida, Periyonix excavator and Eudrilus euginea which were commonly recorded from Sri Lankan soils were evaluated for vermicomposting. Vermicomposting has increased the quality of organic material but the mean differences in nutrient levels in relation to earthworm species were non-significant $(P=0.05)$. This indicates the suitability of all three species for vermicomposting. In the third experiment three soil amendments, vermicompost produced using Eudrilus euginea, garden compost and inorganic fertilizer were compared using tomato as an indicator crop. Vermicompost applied treatment showed significantly higher $(P<0.05)$ fruit weight and number of branches when compared to other two treatments showing its usefulness as a soil amendment. This study shows that all factors are in place for producing vermicompost successfully in Sri Lanka.
\end{abstract}

Keywords- Earthworms, Eudrilus euginea, Periyonix excavator, Eisenia foetida, bedding material, vermicompost.

\section{INTRODUCTION}

In the recent years earthworms have been identified as a major tool for producing high quality compost due to their ability to convert organic waste into valuable plant nutrients and organic matter (Sharma, 2009). In the food web earthworms are regarded as decomposers, detritivores and diggers. They swallow mineral particles and plant debris, partially pushing through the soil and partially eating its way. They are mixed in their gut and pass out as casts on the surface of the soil (Nardi, 2007). Many authors have stated about the process of "feeding high and burrowing low," carried out by the earthworms to physically improve soil structure by enabling pathways for aeration, water infiltration and root penetration. Earthworms are known as "living plow", "best tiller", "farmer's friend", "intestine of earth", "pulse of the soil" as it digest earth and litter leaving behind a rich humus layer, most probably the nature's best fertilizer or known as "black gold" (Ansari and Ismail, 2012; Megraw, 2012; Siddaraju et al, 2013; Lorson, 2016). This was also highlighted by the Charles Darwin in his last manuscript written in 1881 titled "The Formation of Vegetable Mould, Through the Action of Worms". Darwin observed and recorded the habits of the earthworms and its effect on soil formation. Darwin learned that worms literally move the earth in the process of their meanderings. Their passage through the earth aerates the soil and the natural chemistry of their guts renders soil and plant matter into fertile pellets. As a by-product of their movements, worms deposit new soil on the surface, causing whatever was on top to slowly submerge" (Megraw, 2012).

About 3,627 species of terrestrial earthworms have been reported from different parts of the world and 63 species of earthworms from Sri Lanka (Reynolds, 1994). A recent study has revealed 22 species of earthworms belonging to 16 genera and 9 families in 17 natural and agricultural sites in the wet and intermediate zones of Sri Lanka 
(Samaranayake, 2008). Earthworms categorized into three ecological types, namely epigeic, endogeic and anecic based on morphological features, habits and location in soil (Bouche, 1977). Epigeic earthworms are adapted to living close to the soil surface and are capable of eating and decaying organic material such as garbage and litter. They have a short life cycle and small segmented body. Eudrilus euginea, Periyonix excavator and Eisenia foetida are some common epigeic earthworm species found in Sri Lankan soils (Samaranayake and Wijekoon, 2010).

This burrowing and feeding activity of earthworms have numerous beneficial effects on overall soil quality for crop production. Typical earthworm populations can easily consume 5 tons of dry matter per ha per year, partly digesting and mixing it with soil. It is also estimated that for a single acre of cultivated land, earthworms move 8 tons of earth in a year, enough to form a new layer of earth 2 inches thick, rich in nitrogen, phosphorus and calcium (Megrow, 2012). Earthworm casts have higher available N, $\mathrm{P}, \mathrm{K}$ and $\mathrm{Ca}$ contents than surrounding soil, as well as a higher cation-exchange capacity (Jones, 2013; Aladesida et al, 2014; Sherman, 2017). The excrement of earthworms are rich in micronutrients, such as $\mathrm{Zn}$ and $\mathrm{B}$ through chelation. Earthworms also excrete material that has high concentrations of beneficial microbes that help decompose crop residue. The increase in porosity created by earthworms facilitating quick water infiltration into the soil and reduce the effects of compaction is highly advantageous in the no-till systems of farming. $\mathrm{pH}$ buffering action of organic molecules produced in the gut of worms is another advantage of earthworms (Jones, 2013; Aladesida et al, 2014; Sherman, 2017).

Decomposition of waste materials using earthworms is known as vermicomposting (Sharma, 2009; Ansari and Ismail, 2012). Vermicmpost is accepted as humus, bio fertilizer, soil fertility booster, soil activator and soil conditioner with required plant nutrients, vitamins, enzymes, growth hormones and beneficial microbes like nitrogen fixing, phosphate solubilizing, denitrifying and decomposing bacteria.

Tea industry provides several biodegradable waste or byproducts during field operations as well as during tea manufacturing. They include refuse tea, instant tea wastes, shade tree loppings, tea prunings and weeds. In Sri Lanka about 4-6 percent of the total product of made tea goes as refuse tea (Rupasinghe, 2006).

The past research has reported that quality of vermicompost is influenced by the earthworm species and the bedding material (Manaf et al,2009; Bisen et al, 2011; Yadav et al, 2013). Eudrilus euginea, Periyonix excavator and Eisenia foetida are three common earthworm species recorded in Sri Lanka and are being been used for composting worldwide especially in India (Suthar and
Singh, 2008; Manaf et al, 2009; Bisen et al, 2011; Anandharaj et al, 2013; Siddaraju et al, 2013; Perera and Nanthakumaran, 2015). The objective of this study was to examine the suitability of three common earthworm species and some waste materials generated in tea estates as bedding material for earthworms for producing vermicompost.

\section{MATERIALS AND METHODS} Experimental site

Three experiments were conducted during this study to achieve objectives. First and second experiments were conducted at the Erin Tea Estate, Galaha during August to September, 2016. The estate is located in the mid country wet zone (agro-ecological region $\mathrm{WM}_{2}$ ). The Mean minimum and maximum temperature during the research time period was $17^{\circ} \mathrm{C}$ and $27^{\circ} \mathrm{C}$, respectively. The third experiment was conducted at the University Experimental Station, Dodangolla, Kundasale during September to November, 2016. It is located in the mid country intermediate zone (agro-ecological region IM3a). The soil group of this area is Immature Brown Loam and Reddish Brown Latasolic. The Mean minimum and maximu $\mathrm{m}$ temperature during the research period was $20.6^{\circ} \mathrm{C}$ and $29^{0} \mathrm{C}$, respectively.

\section{Multiplication of Earthworms}

Earthworm species Eudrilus euginea and Periyonix excavator were collected from cow dung heaps in Erin Tea Estate, Galaha. Eisenia foetida were collected from partly decomposed vegetable refuse from the Nuwara Eliya area. Multiplication of earthworms were done using a mother compost media stored in a $30 \mathrm{~cm} \times 25 \mathrm{~cm} \times 45 \mathrm{~cm}$ plastic pots. Plastic pots were filled with $3 \mathrm{~cm}$ layer of stones, $3 \mathrm{~cm}$ layer of brick pieces, $5 \mathrm{~cm}$ layer of soil and $20 \mathrm{~cm}$ layer of bedding material kept from bottom to top and placed under closed room conditions. Mixture of vegetable refuse, gliricidia leaf, wild sunflower leaf, banana stem and cow dung were used as the bedding material. After filling the pots with bedding material they were kept for two weeks to allow partial decomposition before introducing the earthworms. Top of the Plastic pots were covered with one layer of newspaper. Watering was done on a need basis and kept for one month for multiplication.

\section{Experiment 1: Evaluation of bedding material for Vermicompost production}

In the first experiment four waste materials commonly occur in tea plantations, the leaves of Gliricidia sepium and Mana (Cymbopogon confertiflorus), tea prunings and one month old refuse tea was composted using earthworm species Eudrilus euginea. Each bedding material were mixed either with one week old cow dung or one year old 
poultry manure at 1: 2 ratio to have eight treatment combinations. The experimental design was a Complete Randomized Design with eight treatment combinations and three replicates. Watering was done on a need basis and kept for two months for vermicompost production.

\section{Experiment 2: Evaluation of Earthworm Species for Vermicompost production}

In the second experiment Eudrilus euginea, Periyonix excavator and Eisenia foetida were evaluated for vermicomposting with respect to $\mathrm{N}, \mathrm{P}$ and $\mathrm{K}$ level in the produced compost. The waste material mixture consisting Gliricidia leaf, tea prunings, mana leaf and refuse tea was blended with either cow dung or poultry manure before using as a bedding material. Hence there were six treatment combinations. The experimental design was a Complete Randomized Design with three replicates. Watering was done on a need basis and kept for two months for vermicompost production.

\section{Measurements - Experiments 1 and 2}

Total Nitrogen, Phosphorus and Potassium content, Electrical Conductivity and $\mathrm{pH}$ values of bedding material were measured before adding earthworms and also after two months of vermicomposting. Total Nitrogen, phosphorus and potassium contents were measured using micro kjeldhal method, spectrophotometer and flamephotometer, respectively. Conductivity meter and $\mathrm{pH}$ meter were used to measure $\mathrm{EC}$ and $\mathrm{pH}$, respectively. Earthworms weighing fifty grams were added to $100 \mathrm{~g}$ of mother compost at each of the experimental units during experiment 1 and 2 .

\section{Experiment 3: Evaluation of Vermicompost as a soil amendment.}

Vermicompost produced from tea waste + poultry manure with Eudrilus euginea (T1) was compared with garden compost (T2) and inorganic fertilizer (T3). Twenty one day old same sized tomato plants from Thilina variety were used as the indicator crop in the experiment. Plastic pots were used for this experiment and they were filled with soil 5 days prior to planting of tomato plants. Both vermicompost and garden compost were added at the rate of $400 \mathrm{~g}$ per pot. The fertilizer recommendation of the Department of Agriculture for tomato was applied under the inorganic fertilizer treatment. Application of water was done on a regular basis. Staking was practiced on 14th day after planting. Plant Height, Number of Leaves, Number of Leaflets, Number of Flowers, Number of branches, Number of fruits were measured at $1^{\text {st }}, 2^{\text {nd }}, 3^{\text {rd }}$ and $4^{\text {th }}$ week after planting. The experimental design was a Complete Randomized Design with three treatments and three replicates.

\section{Data analysis}

Data were analyzed using Statistical Analysis System (SAS) software package. Parametric data were analyzed using analys is of variance (ANOVA) and non-parametric data with categorical data analysis procedures. Significant means of treatments were separated using the Least Significant Difference Test (LSD).

\section{RESULTS AND DISCUSSION}

Experiment 1: Evaluation of bedding material for Vermicompost production

Total Nitrogen, Phosphorus, Potassium, Electrical Conductivity and $\mathrm{pH}$ values of bedding materials and vermicompost produced by the earthworm species Eudrilus euginea is given in the Table 1. The results indicates that vermicomposting has increased Nitrogen, Phosphorus, and Potassiumcontents and also the Electrical Conductivity. $\mathrm{pH}$ has decreased as a result of earthworm activity. It was also revealed that mean differences in $\mathrm{N}, \mathrm{P}$ and $\mathrm{K}$ contents among different treatments were nonsignificant $(\mathrm{P}=0.05)$. Hence, it can be concluded from this study that the biodegradable waste and by-products generated during field operations and tea manufacturing such as refuse tea, shade tree loppings, tea prunings and weeds can be used as suitable bedding material for earthworms to produce high quality compost.

Table.1: Quality of vermicompost produced using Eudrilus eugine and different bedding materials.

\begin{tabular}{|l|c|c|c|c|c|c|c|c|c|c|}
\hline Trt.. & \multicolumn{2}{|c|}{$\mathrm{N}^{\left(\mathrm{mg} \mathrm{g}^{-1}\right)}$} & \multicolumn{2}{|c|}{$\mathrm{P}\left(\mathrm{mg} \mathrm{g}^{-1}\right)$} & \multicolumn{2}{|c|}{$\mathrm{K}^{-\mathrm{mg} \mathrm{g}^{-1}}$} & \multicolumn{3}{|c|}{$\mathrm{PH}$} & \multicolumn{2}{|c|}{$\mathrm{EC}\left(\mathrm{mS} \mathrm{cm}^{-1}\right.$} \\
\cline { 2 - 12 } & $\mathrm{BM}$ & $\mathrm{VC}$ & $\mathrm{BM}$ & $\mathrm{VC}$ & $\mathrm{BM}$ & $\mathrm{VC}$ & $\mathrm{BM}$ & $\mathrm{VC}$ & $\mathrm{BM}$ & $\mathrm{VC}$ \\
\hline T1 & 7.03 & 7.40 & 0.93 & 0.97 & 7.69 & 7.73 & 8.38 & 8.06 & 2.17 & 2.47 \\
\hline T2 & 8.90 & 8.90 & 0.93 & 0.96 & 8.59 & 8.61 & 8.06 & 7.85 & 3.19 & 3.77 \\
\hline T3 & 4.20 & 4.47 & 0.50 & 0.54 & 7.90 & 7.92 & 8.19 & 7.72 & 2.48 & 2.91 \\
\hline T4 & 6.97 & 7.30 & 1.70 & 1.73 & 9.10 & 9.13 & 8.55 & 8.23 & 3.38 & 3.93 \\
\hline T5 & 5.00 & 5.40 & 0.71 & 0.74 & 7.91 & 7.94 & 8.95 & 8.82 & 2.47 & 2.87 \\
\hline T6 & 7.07 & 7.37 & 1.31 & 1.33 & 7.77 & 7.79 & 8.06 & 7.49 & 3.51 & 3.85 \\
\hline T7 & 4.17 & 4.43 & 1.14 & 1.16 & 10.69 & 10.72 & 8.15 & 7.12 & 2.87 & 3.17 \\
\hline T8 & 4.47 & 4.67 & 0.62 & 0.65 & 11.63 & 11.66 & 8.22 & 7.16 & 3.91 & 4.18 \\
\hline
\end{tabular}

Key: Trt-Treatments, BM-Bedding material, VCVermicompost

Treatments: T1 - Gliricidia + Cow dung, T2 - Tea prunings + Cow dung, T3 - Mana + Cow dung, T4 Refuse tea + Cow dung, T5 - Gliricidia + Poultry manure, T6 - Tea prunings + Poultry manure, T7 - Mana + Poultry manure, T8 - Refuse tea + Poultry manure.

\section{Experiment 2: Evaluation of Earthworm Species for Vermicompost production}

Total Nitrogen, Phosphorus, Potassium, Electrical Conductivity and $\mathrm{pH}$ values of bedding materials and vermicompost produced by the earthworm species Eudrilus euginea, Periyonix excavator and Eisenia foetida are given in the Table 2 . The results indicates that vermicomposting has increased Nitrogen, Phosphorus, and Potassium contents and also the Electrical Conductivity. 
$\mathrm{pH}$ has decreased as a result of earthworm activity. It was also revealed that mean differences in $\mathrm{N}, \mathrm{P}$ and $\mathrm{K}$ contents in the vermicompost produced by applying different treatments were non-significant $(\mathrm{P}=0.05)$. Hence, the study confirms that all three earthworm species evaluated in this study are suitable for producing high quality vermicompost.

Table.2: Quality of vermicompost produced by the earthworm species Eudrilus euginea, Periyonix excavator and Eisenia foetida.

\begin{tabular}{|l|l|l|l|l|l|l|l|l|l|l|}
\hline \multirow{2}{*}{ Trt } & \multicolumn{2}{|c|}{$\mathrm{N}^{\left(\mathrm{mg} \mathrm{g}^{-1}\right)}$} & \multicolumn{2}{|c|}{$\mathrm{P}\left(\mathrm{mg} \mathrm{g}^{-1}\right)$} & \multicolumn{2}{c|}{$\mathrm{K}^{\left(\mathrm{mg} \mathrm{g}^{-1}\right)}$} & \multicolumn{3}{|c|}{$\mathrm{PH}$} & \multicolumn{2}{|c|}{$\mathrm{EC}\left(\mathrm{mS} \mathrm{cm}^{-1} \mid\right.$} \\
\cline { 2 - 12 } & BM & VC & BM & VC & BM & VC & BM & VC & BM & VC \\
\hline T1 & 10.16 & 10.64 & 0.57 & 0.87 & 8.94 & 9.12 & 8.67 & 7.07 & 0.75 & 1.85 \\
\hline T2 & 10.01 & 10.34 & 1.62 & 1.92 & 12.08 & 12.33 & 8.73 & 6.83 & 3.20 & 5.40 \\
\hline T3 & 10.20 & 10.52 & 0.69 & 0.96 & 10.08 & 10.42 & 8.50 & 7.00 & 1.21 & 3.58 \\
\hline T4 & 10.84 & 11.22 & 1.54 & 1.95 & 12.52 & 12.82 & 8.73 & 6.80 & 2.72 & 5.61 \\
\hline T5 & 10.71 & 11.03 & 0.33 & 0.66 & 8.84 & 9.18 & 8.43 & 7.23 & 1.42 & 2.38 \\
\hline T6 & 9.65 & 10.06 & 2.17 & 2.61 & 10.57 & 10.95 & 8.67 & 6.93 & 2.53 & 4.80 \\
\hline
\end{tabular}

Key: Trt-Treatment, BM-Bedding material, VCVermicompost

Treatments: $\mathrm{T} 1-$ E. euginea + Cowdung, $\mathrm{T} 2-P$. excavator + Cowdung, T3 - E. foetida + Cowdung, T4 E. euginea + Poultry manure, T5 $-P$. excavator + Poultry manure, T6 - E. foetida + Poultry manure

\section{Experiment 3: Evaluation of Vermicompost as a soil amendment.}

In this experiment vermicompost produced from tea waste + poultry dung with Eudrilus euginea was compared with garden compost and inorganic fertilizer by taking tomato as an indicator crop. Vermicompost applied treatment showed significantly higher $(\mathrm{P}<0.05)$ fruit weight $(\mathrm{g} / \mathrm{plant})$ and number of branches per plant when compared to other two treatments (Table 3). This shows that vermicompost is a useful soil amendment for producing vegetables such as tomato.

Table.3: Number of branches produced at weekly intervals and mean fruit weight ( $\mathrm{g} / \mathrm{plant}$ ) of tomato in

\begin{tabular}{|c|c|c|c|c|}
\hline \multirow{2}{*}{$\begin{array}{l}\text { Treatment } \\
\text { WAP }\end{array}$} & \multicolumn{3}{|c|}{ Number of branches } & \multirow{2}{*}{$\begin{array}{c}\text { Mean fruit } \\
\text { weight } \\
\text { (g/plant) }\end{array}$} \\
\hline & $2 \mathrm{WAP}$ & $3 \mathrm{WAP}$ & 4WAP & \\
\hline Vermicompost & $5.46^{\mathrm{c}} \pm 0.49$ & $5.77^{\mathrm{b}} \pm 0.70$ & $6.38^{\mathrm{b}} \pm 0.49$ & $363.9^{\mathrm{b}} \pm 52.8$ \\
\hline $\begin{array}{l}\text { Garden } \\
\text { compost }\end{array}$ & $1.27^{\mathrm{a}} \pm 0.12$ & $1.27^{\mathrm{a}} \pm 0.12$ & $1.69^{\mathrm{a}} \pm 0.26$ & $128.3^{\mathrm{a}} \pm 9.48$ \\
\hline $\begin{array}{l}\text { Inorganic } \\
\text { fertilizers }\end{array}$ & $2.68^{b} \pm 0.43$ & $2.68^{\mathrm{a}} \pm 0.43$ & $2.99^{\mathrm{a}} \pm 0.38$ & $134.7^{\mathrm{a}} \pm 15.00$ \\
\hline LSD & 1.32 & 1.65 & 1.35 & 111.3 \\
\hline
\end{tabular}

Key: WAP-Weeks after planting, LSD-Least Significant Difference.

Difference of means denoted by same letter are nonsignificant.

\section{CONCLUSIONS}

The results of the experiment shows that waste material generated from field operations of tea plantations and tea manufacturing such as Gliricidia leaf, tea prunings, mana leaf and refuse tea after mixing with cow dung or poultry manure can be used successfully as bedding material for earthworms for producing vermicompost. The study also shows that Eudrilus euginea, Periyonix excavator and Eisenia foetida are suitable earthworm species for vermicomposting. Further it is observed that vermicompost is a useful soil amendment when compared to garden compost and inorganic fertilizer for the successful culture of tomato. Similar results have been reported by many authors including Chanda et al, (2011), Tringovska and Dintcheva, (2012) and Basheer and Agrawal, (2013) when vermicompost was used in the growing media for tomato.

Based on the results of this study it can be concluded that there is a high potential for developing vermitech as a technology for improving soil fertility for crop production systems in Sri Lanka.

\section{REFERENCES}

[1] Aladesida, A.A., Dedeke, G.A, Ademolu, K. and F. Museli, F. (2014). Nutrient analysis of three earthworm cast-types collected from Ikenne, Ogun State, Nigeria. Journal of Natural Science Engineering and Technology, 13:36-43.

Available at:

https://www.researchgate.net/publication/29960817 5_Nutrient_Analysis_of_Three_Earthworm_CastTypes collected from Ikenne Ogun State. [Accessed 14 October 2018].

[2] Anandharaj, M., Sivasankari, B., Indumathi, S. (2013). A Study on life cycle of Earthworm Eudrilus eugeniea. International Journal of Pharmacy and Life Sciences (IJRPLS). 1(2):64-67.

[3] Ansari, A.A. and Ismail, S.A. (2012). Role of Earthworms in Vermitechnology. Journal of Agricultural Technology, 8(2):403-415.

[4] Basheer, M., and Agrawal, O. P. (2013). Effect of Vermicompost on the Growth and Productivity of Tomato Plant (Solanum Lycopersicum) Under Field Conditions. International Journal of Recent Scientific Research, 4(3), 247-249.

[5] Bisen, J.S., Singh, A.K., Kumar, R., Bora, D.K. and Bera, B. (2011). Vermicompost quality as influenced by different species of earthworm and bedding material. Two and a Bud 58:137-140.

[6] Chanda, G. K., Bhunia, G., and Chakraborty, S. K. (2011). The effect of vermicompost and other fertilizers on cultivation of tomato plants. Journal of Horticulture and Forestry, 3(2): 42-45. 
[7] Jones, J.B. (2013). The fertilizer value of worm castings. Fertilizer and Plant Nutrition Articles.

Available at:

https://www.gardenandgreenhouse.net/articles/plantnutrition-articles/the-fertilizer-value-of-wormcastings/ [Accessed 14 October 2018]

[8] Lorson, J. (2016). The lowly earthworm is actually a living plow. Available at:

https://www.farmanddairy.com/columns/the-lowlyearthworm-is-actually-a-living-p low/314496.ht ml [Accessed 25 August 2018]

[9] Manaf, L.A., Jusoh, M.L.C., Yusoff, M.K., Hanidza, T., Ismail, T., Harun, R. and Juahir, H. (2009). Influences of Bedding Material in Vermicomposting Process. International Journal of Biology. 1(1): 8191.

[10] Megraw, J. (2012). The importance of earthworms: Darwin's last manuscript. Available at: HTTPS://WWW.NYPL.ORG/BLOG/2012/04/19/E ARTHWORMS-DARWINS-LAST-MANUSCRIPT [Accessed 25 August 2018]

[11] Nardi, J.B. (2007). Life in the soil: a guide to naturalists and gardners. The University of Chicago. 293p.

[12] Perera, K.I.M. and Nanthakumaran, A. (2015). Technical feasibility and effectiveness of vermicomposting at household level. Tropical Plant Research: 2(1): 51-57.

[13] Reynolds, J.W. (1994). Earthworms of the world. Global Biodiversity. 4(1): 11-16.

[14] Rupasinghe, K., and Nandasena, K. (2006). Potential exploitation of refuse tea as an alternative medium in mushroom cultivation. Tropical Agricultural Research. 18(51).

[15] Samaranayake, J.W.K. (2008). Distribution and ecology of earthworms in selected habitats in Sri Lanka with emphasis on soil fertility and vermicomposting. (MPhil Thesis). Postgraduate Institute of Science, University of Peradeniya, Sri Lanka. 217p.

[16] Samaranayake, J. W. K. and Wijekoon, S. (2010). Effect of Selected Earthworms on Soil Fertility, Plant Growth and Vermicomposting. Tropical Agricultural Research and Extension, 13(2): 34-40.

[17] Sharma, K.A. (2009). A hand book of organic farming. Agrobios, India. 627p.

[18] Sherman, R. (2017). Earthworm castings as plant growth media. North Carolina Cooperative Extension.

Available at: http://www.wonderworms.com/wpcontent/uploads/2017/04/North-Carolina-State-

Earthworm-castings-as-plant-growth-media..pdf

[Accessed 14 October 2018].
[19] Siddaraju, M., Sreepada, K.S. and Krishna, M.P. (2013). Recorded Distribution of Earthworms of the Family Octochaetidae In Dakshina Kannada District, South West Coast, Karnataka. International Journal of Scientific and Research Publications, 3(6).

[20] Suthar, S. and Singh, S. (2008). Vermicomposting of domestic waste by using two epigeic earthworms (Perionyx excavatus and Perionyx sansibaricus). International Journal of Environmental Science Technology, 5 (1): 99-106.

[21] Tringovska, I., and Dintcheva, T. (2012). Vermicompost as Substrate Amendment for Tomato Transplant Production. Sustainable Agriculture Research, 1(2), 115-122.

[22] Yadav, A., Gupta, R. and Garg, V.K. (2013). Organic manure production from cow dung and biogas plant slurry by vermicomposting under field conditions. International Journal of Recycling of Organic Waste in Agriculture 2:21. 